\title{
Pengembangan Media Pembelajaran Berbasis Game Edukasi Pada MatPel IPA Tematik Kebersihan Lingkungan
}

\author{
Reni Widyastuti ${ }^{1}$, Listia Sari Puspita ${ }^{2}$ \\ ${ }^{1}$ Universitas Bina Sarana Informatika \\ e-mail: reni.rws@bsi.ac.id \\ ${ }^{2}$ Lembaga Ilmu Pengetahuan Indonesia \\ e-mail: listia.sari.puspita@lipi.go.id
}

\begin{abstract}
Game is one of the interactive multimedia products which is developing rapidly in the world, including Indonesia. Educational games can be used as an alternative interactive learning media that has the goal of supporting the learning process with the concept of "playing while learning". The educational game aims to stimulate students to understand the material provided by the teacher and help teachers provide alternative teaching methods that are fun for students. Environmental cleanliness is a learning theme for grade 1 elementary school presented on Natural Sciences (IPA) subjects. First grade elementary school students are early students who want fun learning so the purpose of this research is to create an educational mobile game application that can be used for learning media for elementary school class I science that can motivate students to learn, understand and apply environmental cleanliness starting from home, school and can distinguish waste that can be recycled or not. In the construction of this game using the version 2 construct application with system development with the waterfall system development method.
\end{abstract}

Keywords: Kebersihan Lingkungan, Multimedia interaktif, Construct 2.0, Waterfall

\section{PENDAHULUAN}

Game edukasi merupakan permainan yang dibuat untuk merangsang daya pikir termasuk meningkatkan konsentrasi dan memecahkan masalah. Teknik pembelajaran interaktif yang efektif bagi anak usia dini adalah dengan menggunakan Game edukasi, hal ini dikarenakan sebagian besar anak di usia dini memiliki rasa ingin tahu yang tinggi terhadap semua yang berada di lingkungan sekitarnya (R. A. Rahman \& Tresnawati, 2016). Game dibuat memiliki tujuan khusus education (mendidik). Game edukasi ini akan mengutamakan untuk mendukung proses pembelajaran dengan konsep bermain sambil belajar. Untuk sebagian anak, kata belajar akan terasa sangat menakutkan, sehingga diharapkan dengan adanya game pendidikan yang menarik ini, anak tidak akan menyadari jika yang dilakukannya itu adalah termasuk belajar dan anak akan menjadi senang dan mau belajar (Siswanto \& Putra, 2013).

Segala sesuatu yang menyangkut pendidikan, baik sistem, strategi, serta proses di dalamnya tidak lain kecuali diarahkan hanya untuk mencapai pendidikan yang bermutu dan berkualitas. (Sintya Maharani, 2015)

Mata pelajaran Ilmu Pengetahuan Alam (IPA) untuk kelas 1 SD dengan tematik kebersihan lingkungan akan lebih menarik minat anak usia dini dengan menerapkan konsep bermain sambil belajar. Game Edukasi ini berguna agar siswa dapat memahami pentingnya kebersihan lingkungan dan dapat membantu guru dalam memilih alternatif metode pembelajaran sehingga mendapatkan perhatian siswa memahami penjelasan dari guru.

\section{METODOLOGI PENELITIAN}

1. Metode pengumpulan data

Metode pengumpulan data yang penulis gunakan dalam pembuatan skripsi ini adalah sebagai berikut:

A. Observasi

Penulis melakukan pencatatan, pengumpulan data serta melakukan pengamatan dengan langsung SDN 06 Rawabadak Selatan , Jakarta Utara untuk mengamati proses belajar mengajar.

B. Wawancara

Metode ini dilakukan dengan tanya jawab dengan guru dan kepala sekolah SDN 06 Rawabadak Selatan, Jakarta Utara

C. Studi Pustaka

Dengan metode ini dapat membantu penulisan dalam hal pembuatan skripsi yang ditunjang dengan beberapa literatur yang berhubungan dengan mempelajari buku-buku, jurnal, dan bahan pustaka lainnya

\section{Kajian Literatur}

\section{a. Media Pembelajaran}

Media pembelajaran adalah media yang dirancang secara khusus untuk merangsang pikiran, perasaan, perhatian, dan kemauan peserta didik 
sehingga terjadinya proses pembelajaran. Media pembelajaran memuat informasi yang dapat berupa pengetahuan maupun menjadi sarana bagi siswa untuk melakukan aktivitas belajar (membaca, mengamati, mencoba, mengerjakan soal, menjawab pertanyaan, dan lain-lain). Media pembelajaran bukan sekedar benda fisik, namun segala sesuatu yang sudah berisi materi pembelajaran, sehingga memungkinkan seseorang memanfaatkannya untuk belajar guna memperoleh pengetahuan, keterampilan, atau perubahan sikap (S. Rahman et al., 2016).

Sehingga peranan media adalah Peranan media pembelajaran dalam proses belajar dan mengajar sangat penting dilaksanakan oleh para pendidik saat ini, karena peranan media pembelajaran dapat digunakan untuk menyalurkan pesan pengirim kepada penerima dan melalui media pembelajaran juga dapat membantu peserta didik untuk menjelaskan sesuatu yang disampaikan oleh pendidik. Dengan penggunaan alat-alat ini guru dan siswa dapat berkomunikasi lebih mantap dan hidup serta interaksinya bersifat banyak arah. Media mengandung pesan sebagai perangsang belajar dan dapat menumbuhkan motivasi belajar sehingga siswa tidak menjadi bosan dalam meraih tujuantujuan belajar (Tafonao, 2018)

Berikut ini merupakan fungsi media pembelajaran (Adam, 2015) yaitu :

1. Fungsi Media Pembelajaran Sebagai Sumber Belajar Secara teknis, media pembelajaran sebagai sumber belajar. Dalam kalimat sumber belajar ini tersirat makna keaktifan yaitu sebagai penyalur, penyampai, penghubung dan lain-lain. Fungsi media pembelajaran sebagai sumber belajar adalah fungsi utamanya disamping adanya fungsi-fungsi lainnya.

2. Fungsi Semantik Fungsi semantik adalah kemampuan media dalam menambah pembendaharaan kata yang makna atau maksudnya benar-benar dipahami oleh anak didik. Bahasa meliputi lambang (simbol) dari isi yakni pikiran atau perasaan yang keduanya telah menjadi totalitas pesan yang tidak dapat dipisahkan.

3. Fungsi Manipulatif Fungsi manipulatif ini didasarkan pada ciri-ciri umum yaitu kemampuan merekan, menyimpan, melestarikan, merekonstruksikan dan metransportasi suatu peristiwa atau objek. Berdasarkan karakteristik umum ini, media memiliki dua kemampuan, yakni mengatasi batas-batas ruang dan waktu, mengatasi keterbatasan inderawi.

4. Fungsi Psikologis, yang terdiri dari:

- Fungsi Atensi

- Fungsi Afektif

- Fungsi Kognitif

- Fungsi Imajinatif

- Fungsi Motivasi

\section{- Fungsi Sosio-Kultural}

\section{b. Pendekatan Air Terjun (Waterfall Approach)}

Pendekatan sistem dengan Metode SDLC yang disebut pendekatan air terjun (waterfall approach) dalam tahapan pengembangan sistem. Model ini menggunakan pendekatan secara sistematis dan urut mulai dari level kebutuhan sistem lalu ketahap analisis, design, coding, testing, dan support atau maintenance. Tahapan waterfall (air terjun) tersusun bertingkat, setiap tahap dalam model ini dilakukan berurutan, seperti gambar dibawah berikut :

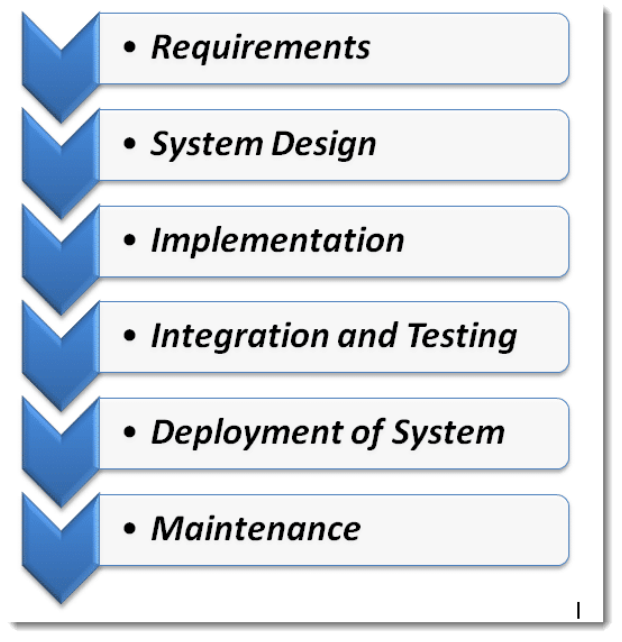

Sumber : (Lakshay \& toolsqa.com, 2016) Gambar 1. Model Waterfall

Waterfall atau dikenal dengan model air terjun ini menyediakan pendekatan alur hidup perangkat lunak secara sekuensial atau terurut. Adapun tahapannya adalah:

1. Requirement Analysis Pada tahapan ini penulis melakukan pengumpulan kebutuhan secara intensif untuk menspesifikasikan kebutuhan perangkat lunak, seperti siapa yang akan memakai produk ini.

2. System Design Untuk tahap system design ini penulis membuat storyboard untuk menjelaskan tampilan secara terperinci dari aplikasi multimedia interaktif ini. Pada tahap kedua ini, tidak hanya dari sisi software saja yang dianalisa, tetapi juga pada sisi hardware atau perangkat keras yang digunakan untuk aplikasi multimedia interaktif ini

3. Implementation Pada tahap yang ketiga ini, penulis menganalisa unit aplikasi yang telah dibuat ini apakah sudah sesuai dengan rancangan atau belum. Bisa dikatakan pada tahapan ini adalah tahapan uji coba produk

4. Testing Testing ini dilakukan setelah langkah keempat, dimana teknik untuk langkah ini menggunakan Black Box 
Testing. 5. Deployment Pada tahapan ini, dilakukan penggunaan aplikasi pada lingkungan sesuai dengan penggunanya 6 . Maintenance Maintenance merupakan tahpan terakhir dari produk yang dibuat, selain itu juga penulis mengharapkan kedepannya produk yang dibuat ini bisa diperbaiki menjadi lebih baik dari sebelumnya

\section{c. Construct 2.0}

Construct 2 adalah sebuah tool berbasis HTML5 untuk menciptakan sebuah permainan". Tool - tool pada Construct 2 sangat user frendly dimana user dapat dengan mudah membuat game dengan menggunakannya tanpa harus memiliki pengalaman pemrograman. Construct 2 dikembangkan oleh Scirra Ltd memiliki tujuan pembuatan game dengan mudah terutama untuk para non-programmer yang ingin menciptakan sebuah game secara drag and drop menggunakan editor visual dan berbasis sistem logika perilaku (Adiwijaya et al., 2015).

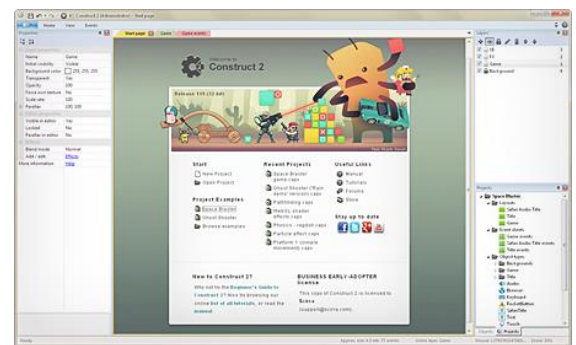

Sumber : https://www.scirra.com/construct2 Gambar 2. Construct2

\section{d. Struktur Navigasi}

Menurut Bimanto dalam (Yuni Eka Achyani, 2018)"Desain interface website yang menarik dan interaktif harus diperhatikan sebelum merancang tampilan web adalah pembuatan struktur navigasi “

Ada empat struktur dasar yang digunakan yaitu linear, hierarkis, nonlinear, dan komposit.

1. Linear

Pengguna akan melakukan navigasi secara berurutan dari frame atau byte informasi yang satu ke yang lainnya

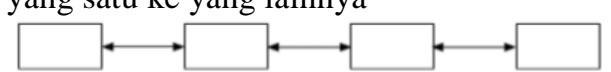

(Sumber: Binanto, 2010)

\section{Hierarkis}

Gambar 3. Struktur Navigasi Linear

Struktur dasar ini disebut juga struktur "linear dengan percabangan" karena pengguna melakukan navigasi disepanjang cabang pohon struktur yang terbentuk oleh logika isi.

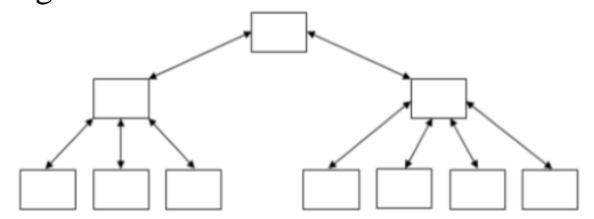

(Sumber: Binanto, 2010)

Gambar 4. Struktur Navigasi Hierarkis

3. Nonlinear

Pengguna akan melakukan navigasi dengan bebas melalui isi proyek dengan tidak terkait dengan jalur yang ditentukan sebelumnya

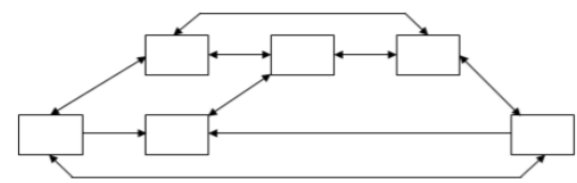

(Sumber: Binanto, 2010)

Gambar 5. Struktur Navigasi Nonlinear

4. Komposit

Pengguna akan melakukan navigasi dengan bebas (secara nonlinear), tetapi terkadang dibatasi presentasi linear film atau informasi penting atau pada data yang paling terorganisasi secara logis pada suatu hierarki

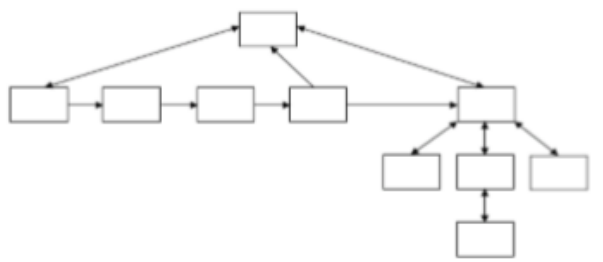

(Sumber: Binanto, 2010)

Gambar 6. Struktur Navigasi Komposit

\section{HASIL DAN PEMBAHASAN}

\section{Hasil}

Penulisan jurnal tentang media pembelajaran untuk siswa kelas 1 SD pada mata pelajaran IPA dengan tema Kebersihan Lingkungan. Media pembelajaran ini menggunakan program Construk versi 2 (dua), Adobe Photoshop dan Adobe Ilustrator. Pada beberapa halaman dan tombolnya diberikan suara, sehingga menambah efek menarik dari aplikasi ini. Aplikasi ini juga mudah digunakan (user friendly), tombol (button) penghubung yang halaman lainnya sehingga memudahkan pengguna.

Struktur penghubung / navigasi yang digunakan adalah Hierarkis dengan gambar sebagai berikut :

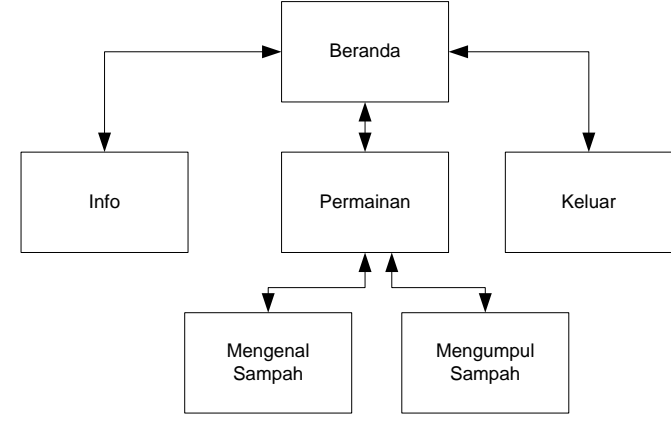

Gambar 7. Struktur navigasi Permainan 
Serta tampilan user interface dari aplikasi ini antara lain :

a. Tampilan Menu Opening

Menu Opening ini berisi tentang judul program animasi yang sedang dimainkan

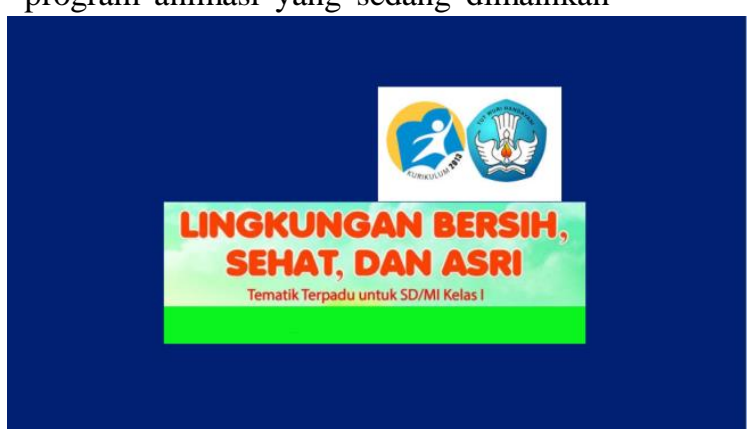

Gambar 7. Opening

b. Tampilan Menu Utama

Menu utama ini berisi 4 tombol yaitu tombol informasi tentang game, Play, suara \& exit

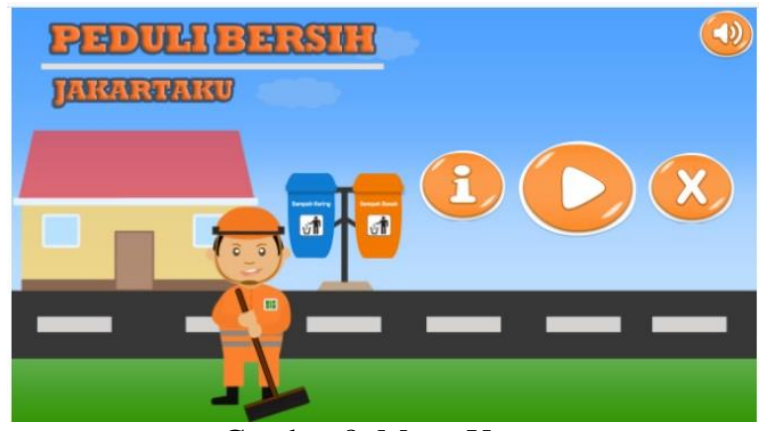

Gambar 8. Menu Utama

c. Tampilan Menu Permainan

Menu utama ini beisikan tombol mengenal sampah, mengumpulkan sampah, menu utama \& suara

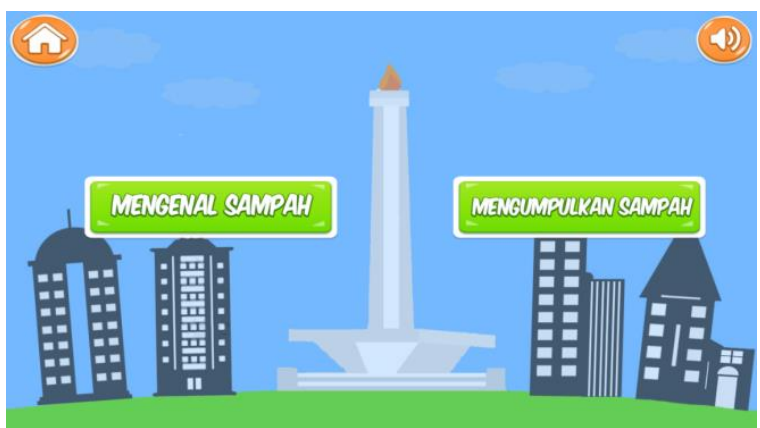

Gambar 9. Menu Play

d. Tampilan menu mengenal jenis sampah

Menu utama ini berisikan tombol menu utama , lanjut \& teks informasi tentang jenis sampah

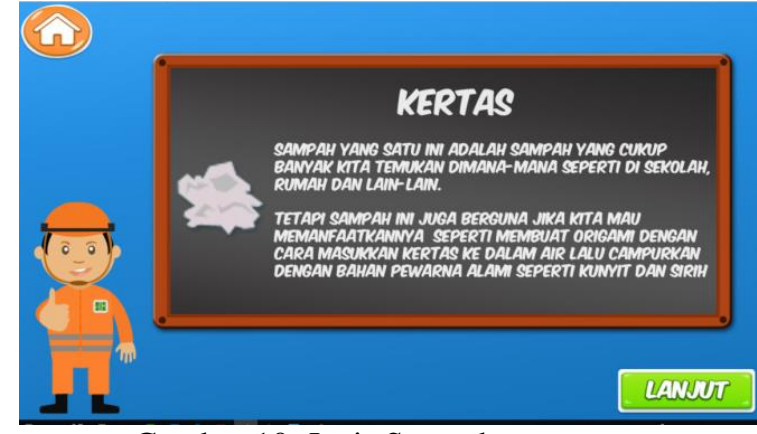

Gambar 10. Jenis Sampah

e. Tampilan Menu Mengumpulkan Sampah

Menu mengumpulkan sampah terdiri dari tombol - tombol yaitu menu utama, suara , cara bermain , 4 area permainan yaitu jakarta utara, jakarta timur, jakarta barat \& jakarta selatan.

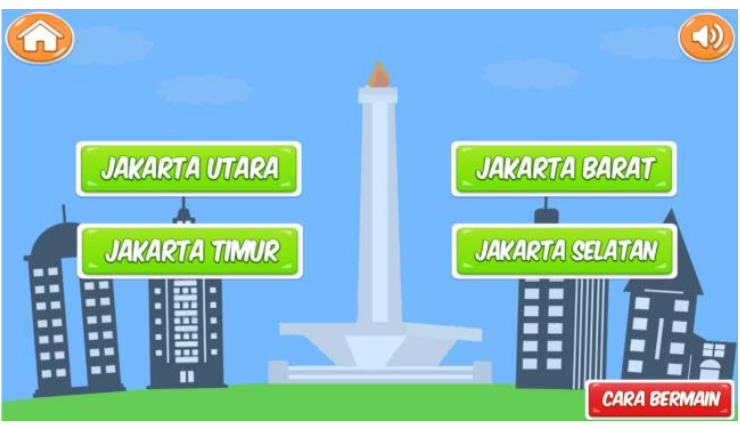

Gambar 11. Menu Mengumpulkan Sampah

f. Tampilan Menu Area Permainan Mengumpulkan Sampah

Menu area permaian terdiri dari waktu permaian \& tombol pause yang terdiri dari play, replay \& Menu utama. Pada area permainan, user dapat clik \& drag gambar sampah ke tong sampah yang disesuaikan kategori sampah organik atau sampah non organik dengan waktu 5 detik di setiap permainan.

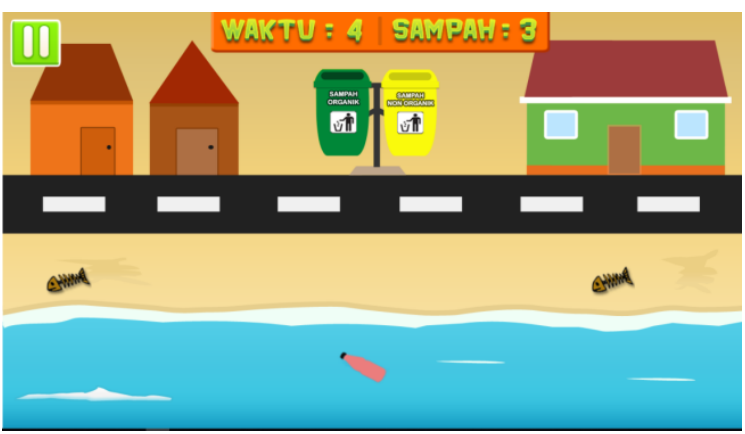

Gambar 12. Menu Area Permainan 
Paradigma - Jurnal Informatika dan Komputer,

Vol. 22 No 1, Maret 2020

P-ISSN 1410-5063, E-ISSN: 2579-3500

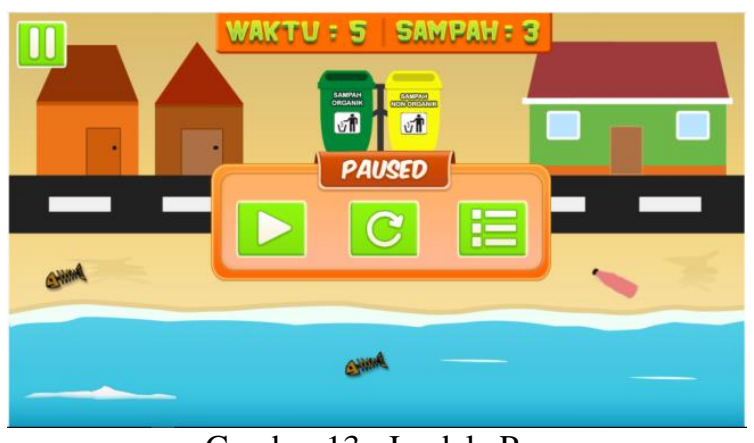

Gambar 13. Jendela Pause

\section{Pengujian}

Metode pengujian yang digunakan adalah black box testng yang bertujuan untuk menunjukkan fungsi operasi perangkat lunak yang digunakan, apakah data masukan dan keluaran telah sesuai yang diharapkan. Berikut ini rencana pengujian dari aplikasi game edukasi IPA tema kebersihan lingkungan pada tabel 1 :

Tabel 1. Rencana Pengujian Aplikasi

\begin{tabular}{|l|l|l|}
\hline Kelas Uji & Detail Pengujian & Jenis Uji \\
\hline Play Button & $\begin{array}{l}\text { Menampilkan area } \\
\text { permainan }\end{array}$ & Black box \\
\hline Exit button & $\begin{array}{l}\text { Keluar dari } \\
\text { permainan }\end{array}$ & Black box \\
\hline $\begin{array}{l}\text { Information } \\
\text { button }\end{array}$ & $\begin{array}{l}\text { Menampilkan } \\
\text { informasi tentang } \\
\text { game edukasi serta } \\
\text { fungsi dari game ini } \\
\text { sebagai media } \\
\text { pembelajaran }\end{array}$ & \\
\hline $\begin{array}{l}\text { Tempat } \\
\text { sampah }\end{array}$ & $\begin{array}{l}\text { Pengujian gambar } \\
\text { sampah dengan klik } \\
\text { dan drag untuk } \\
\text { mendekati tempat } \\
\text { sampah }\end{array}$ \\
\hline
\end{tabular}

Berdasarkan rencana pengujian aplikasi yang telah disusun, maka dapat dilakukan beberapa tahap pengujian sebagai berikut:

Tabel 2. Pengujian Kelas Play Button

\begin{tabular}{|l|l|l|l|}
\hline \multicolumn{4}{|c|}{ Hasil Uji } \\
\hline $\begin{array}{l}\text { Data } \\
\text { Masuka }\end{array}$ & $\begin{array}{l}\text { Yang } \\
\text { diharapkan }\end{array}$ & $\begin{array}{l}\text { Pengujia } \\
\mathrm{n}\end{array}$ & $\begin{array}{l}\text { Kesimpula } \\
\mathrm{n}\end{array}$ \\
\hline $\begin{array}{l}\text { Play } \\
\text { Button }\end{array}$ & $\begin{array}{l}\text { Menampilk } \\
\text { an area } \\
\text { permainan }\end{array}$ & $\begin{array}{l}\text { Memulai } \\
\text { permaina } \\
\mathrm{n}\end{array}$ & $\begin{array}{l}{[\sqrt{ }] \text { Tampil }} \\
{[\text { ] Tidak }}\end{array}$ \\
\hline
\end{tabular}

Tabel 3. Pengujian Kelas Exit Button

\begin{tabular}{|l|l|l|l|}
\hline \multicolumn{4}{|c|}{ Hasil Uji } \\
\hline $\begin{array}{l}\text { Data } \\
\text { Masuka } \\
\mathrm{n}\end{array}$ & $\begin{array}{l}\text { Yang } \\
\text { diharapka } \\
\mathrm{n}\end{array}$ & $\begin{array}{l}\text { Pengujia } \\
\mathrm{n}\end{array}$ & $\begin{array}{l}\text { Kesimpula } \\
\mathrm{n}\end{array}$ \\
\hline $\begin{array}{l}\text { Exit } \\
\text { Button }\end{array}$ & $\begin{array}{l}\text { Keluar } \\
\text { dari } \\
\text { aplikasi } \\
\text { game }\end{array}$ & $\begin{array}{l}\text { Informasi } \\
\text { petunjuk } \\
\text { tombol }\end{array}$ & $\begin{array}{l}{[\sqrt{ }] \text { Tampil }} \\
{[] \text { Tidak }}\end{array}$ \\
& & \\
\hline
\end{tabular}

Tabel 4. Pengujian Kelas Information Button

\begin{tabular}{|l|l|l|l|}
\hline \multicolumn{4}{|c|}{ Hasil Uji } \\
\hline $\begin{array}{l}\text { Data } \\
\text { Masukan }\end{array}$ & $\begin{array}{l}\text { Yang } \\
\text { diharapkan }\end{array}$ & $\begin{array}{l}\text { Penguji } \\
\text { an }\end{array}$ & $\begin{array}{l}\text { Kesimpul } \\
\text { an }\end{array}$ \\
\hline $\begin{array}{l}\text { Informati } \\
\text { on Button }\end{array}$ & Menampilk & Informa & {$[\sqrt{]}]$} \\
& an & si & Tampil \\
informasi & petunju & [ ] Tidak \\
& fungsi \\
game & k & \\
& tombol & \\
& sebagai & & \\
& media \\
pembelajar & & & \\
& an & & \\
\hline
\end{tabular}

Tabel 5. Pengujian Kelas Tempat Sampah

\begin{tabular}{|c|c|c|c|}
\hline \multicolumn{4}{|c|}{ Hasil Uji } \\
\hline $\begin{array}{l}\text { Data } \\
\text { Masuka } \\
\text { n }\end{array}$ & $\begin{array}{l}\text { Yang } \\
\text { diharapka } \\
n\end{array}$ & Pengujian & $\begin{array}{l}\text { Kesimpula } \\
\mathrm{n}\end{array}$ \\
\hline $\begin{array}{l}\text { Cllik \& } \\
\text { Drag }\end{array}$ & $\begin{array}{l}\text { Memilih } \\
\text { ikon } \\
\text { gambar } \\
\text { sampah } \\
\text { ke tempat } \\
\text { sampah } \\
\text { sesuai } \\
\text { kriteria } \\
\text { sampah } \\
\text { organik } \\
\text { atau non } \\
\text { organik }\end{array}$ & $\begin{array}{l}\text { gambar } \\
\text { sampah } \\
\text { akan } \\
\text { menghilan } \\
\text { g jika } \\
\text { mendekati } \\
\text { tempat } \\
\text { sampah } \\
\text { yang } \\
\text { sesuai } \\
\text { kriteria } \\
\text { sampah } \\
\text { apakah } \\
\text { organik } \\
\text { atau non } \\
\text { organik }\end{array}$ & $\begin{array}{l}\text { [ } \sqrt{ } \text { T Tampil } \\
\text { [ ] Tidak }\end{array}$ \\
\hline
\end{tabular}

\section{KESIMPULAN}

Media pembelajaran adalah alat bantu guru untuk menyampaikan materi agar lebih jelas sehingga siswa lebih memahami materi yang disampikan oleh guru. Game edukasi merupakan alternatif media pembelajaran sehingga pelajaran lebih menarik dengan siswa dapat berinteraksi secara langsung khususnya untuk mata pelajaran ilmu pengetahuan alam yang diberikan ke siswa sekolah dasar kelas 1 dengan tema kebersihan sekolah. Tujuan game edukasi ini adalah siswa dapat memahami pentingnya kebersihan dan bisa membedakan jenis sampah organik atau non organik

\section{REFERENSI}

Adam, steffi dan M. T. . (2015). Pemanfaatan Media Pembelajaran Berbasis Teknologi Informasi Bagi Siswa Kelas X Sma Ananda Batam. CBIS Journal, 3 No 2(ISSN 23378794), 78-90. 
Adiwijaya, M., S, K. I., \& Christyono, Y. (2015). Perancangan Game Edukasi Platform Belajar Matematika Berbasis Android Menggunakan Construct 2. Transient, 4(1), 128-133.

Lakshay, S., \& toolsqa.com. (2016). waterfallModel. Www.Toolsqa.Com.

https://www.toolsqa.com/softwaretesting/waterfall-model/

Rahman, R. A., \& Tresnawati, D. (2016). Pengembangan Game Edukasi Pengenalan Nama Hewan dan Habitatnya Dalam 3 Bahasa Sebagai Media Pembelajaran Berbasis Multimedia. Jurnal Algoritma, 13(1), 184190. https://doi.org/10.33364/algoritma/v.131.184

Rahman, S., Munawar, W., \& Berman, E. T. (2016). Pemanfaatan Media Pembelajaran Berbasis Website Pada Proses Pembelajaran Produktif Di Smk. Journal of Mechanical Engineering Education, 1(1), 137. https://doi.org/10.17509/jmee.v1i1.3746

Sintya Maharani, Y. (2015). Efektivitas Multimedia Pembelajaran Interaktif Berbasis Kurikulum 2013 The Effectiveness Of Interactive Learning Multimedia Based On Curriculum 2013. Ijcets, 3(1), 31-40. http://journal.unnes.ac.id/sju/index.php/jktp

Siswanto, Y., \& Putra, B. E. (2013). Rancang Bangun Aplikasi Mobile Game Edukasi Ilmu Pengetahuan Alam Untuk Anak Kelas VI Sekolah Dasar. Rancang Bangun Aplikasi Mobile Game Edukasi Ilmu Pengetahuan Alam Untuk Anak Kelas VI Sekolah Dasar, 5(4),

http://ijns.org/journal/index.php/speed/article/ view/1019

Tafonao, T. (2018). Peranan Media Pembelajaran
Dalam Meningkatkan Minat Belajar Mahasiswa. Jurnal Komunikasi Pendidikan, 2(2), 103. https://doi.org/10.32585/jkp.v2i2.113

Yuni Eka Achyani, E. A. (2018). Sistem Informasi Pe ndapatan Jasa Pada Koperasi PDAM Tirta Patriot Bekasi. Jurnal Teknik Komputer AMIK BSI (JTK), $4(1), \quad$ 1-8. https://ejournal.bsi.ac.id/ejurnal/index.php/jtk/ article/view/2377

\section{PROFIL PENULIS}

Reni Widyastuti, M.Kom, dilahirkan di Jakarta, 29 Oktober 1978. Pada tahun 2002 lulus S-1 dengan program studi Sistem Informatika di STMIK Muhammadiyah dan pada tahun 2013 lulus .S-2 dengan program studi Ilmu Komputer di STMIK Nusa Mandiri. Saya mulai mengajar di STMIK Muhammadiyah dari tahun 2003 - 2005 dan di AMIK BSI sejak tahun 2007 sampai sekarang

Listia Sari Puspita, S.E, dilahirkan di Jakarta, 26 Maret 1984. Pada tahun 2009 lulus S-1 dengan program studi Ekonomi Akutansi di Universitas Mercu Buana. Mulai Bekerja di Lembaga Ilmu Pengetahuan Indonesia dari tahun 2006 sampai saat ini. Saat ini sedang menempuh program Magister Perencanaan Ekonomi dan Kebijakan Publik di Universitas Indonesia. 